\title{
Ruminal Fermentation and Nutrient Digestion by Dairy Cows Fed Varying Amounts of Soyhulls as a Replacement for Corn Grain
}

\author{
I. R. Ipharraguerre, ${ }^{\star}$ Z. Shabi, ${ }^{*}$ J. H. Clark, ${ }^{*}$ and D. E. Freeman† \\ *Department of Animal Sciences and \\ †Department of Veterinary Clinical Medicine, \\ University of Illinois, Urbana 61801
}

\section{ABSTRACT}

Five multiparous Holstein cows cannulated in the rumen and duodenum that averaged $63 \mathrm{~d}$ in milk were used in a $5 \times 5$ Latin square design with 14 -d periods to evaluate the incremental substitution of soyhulls for corn in the diet. Diets contained $23 \%$ alfalfa silage, $23 \%$ corn silage, and $54 \%$ concentrate on a dry matter (DM) basis. Pelleted soyhulls replaced corn in the concentrate to supply $0,10,20,30$, or $40 \%$ of the dietary DM. The intakes of DM and organic matter were unaffected by treatments. Intakes of acid detergent fiber and neutral detergent fiber increased linearly, but the intake of nonstructural carbohydrates decreased linearly as soyhulls increased from 0 to $40 \%$ of dietary DM. The amount of acid detergent fiber and neutral detergent fiber digested was increased whereas the amount of nonstructural carbohydrate digested was decreased in the rumen, in the lower digestive tract, and in the total digestive tract as soyhulls replaced corn in the diet. Passage to the duodenum of nonammonia $\mathrm{N}$, microbial $\mathrm{N}$, nonammonia nonmicrobial $\mathrm{N}$, total essential amino acids, total nonessential amino acids, and total amino acids were not affected by treatments. Yield of milk $(29.5 \mathrm{~kg} / \mathrm{d})$ was not affected by treatments in this experiment. In a companion experiment, cows fed the $40 \% \mathrm{SH}$ diet produced $1.2 \mathrm{~kg} /$ day per cow less $(P<0.07)$ milk than cows fed the control diet which is similar to the $1.3 \mathrm{~kg} /$ day per cow less milk produced by cows fed the same $40 \% \mathrm{SH}$ diet in this experiment. Differences in the source of energy (fiber vs. nonstructural carbohydrates), in the amount of fiber and nonstructural carbohydrates digested, and in the site of digestion in the gastrointestinal tract may cause a shortage of the source and/or amount of energy that is required for maximum milk production in high producing cows when more than $30 \%$ of the dietary DM that is supplied as corn is replaced with soyhullss.

Received December 7, 2002.

Accepted June 15, 2002.

Corresponding author: Jimmy H. Clark; e-mail: jclark@uiuc.edu.
(Key words: dairy cow, nutrient digestion, ruminal fermentation, soyhull)

Abbreviation key: EAA = essential amino acids, MUN = milk urea nitrogen, NANMN = nonammonia nonmicrobial N, NEAA = nonessential amino acids, $\mathbf{N F C}=$ nonfiber carbohydrates, $\mathbf{S H}=$ soyhulls.

\section{INTRODUCTION}

To achieve maximum milk production potential through means acceptable to consumers, feeding systems for dairy cows need to ensure, among other factors, high intake of energy. This goal might be accomplished by raising the dietary concentration of rapidly degradable NSC, like starch from cereal grains. Increasing the concentration of NSC in diets of dairy cows, however, can lead to undesirable ruminal fermentation, compromising the nutrient supply for production of milk and milk components. In fact, it is well documented that feeding large amounts of NSC or nonfiber carbohydrates (NFC) can enhance the production of acids, particularly lactic acid, in the rumen; this increases the incidence of ruminal acidosis (Nocek, 1997) and reduces ruminal $\mathrm{pH}$, fiber digestibility, acetate to propionate ratio, and milk fat content (Erdman, 1988). Additionally, an excess of readily available NSC in the rumen might compromise the efficiency of microbial protein synthesis and the supply of microbial AA to the small intestine because of increased energy spilling by ruminal bacteria (Clark et al., 1992). To prevent ruminal upsets and health problems, the NRC (2001) recommended that the maximum NFC in diets for high producing dairy cows should range from 36 to $44 \%$ depending on the total and forage NDF content of the ration.

The partial replacement of cereal grains with low starch byproduct feeds, such as soyhulls (SH), represents a potential alternative to overcome this limitation (Ipharraguerre and Clark, 2002). For instance, the replacement of 12 and $25 \%$ of the DM in the ration supplied as high moisture corn with SH markedly reduced NFC in the diet from 41 to 34 and $29 \%$, respectively, but still enhanced the total VFA concentration and the 
acetate to propionate ratio in the rumen of dairy cows during early lactation (Cunningham et al., 1993). In this study, diets that contained SH sustained milk yield and secretion of milk components. Similar shifts in ruminal fermentation were reported in a number of studies (Sarwar et al., 1992; Mansfield and Stern, 1994) in which $\mathrm{SH}$ were substituted for corn to supply up to about $30 \%$ of dietary DM. This response seems to result from increases in the amount of fiber digested in the rumen of cows fed diets that contained SH (Cunningham et al., 1993; Mansfield and Stern, 1994). Additionally, the enhancement in digestibility of NDF could be related to the digestible nature of fiber in $\mathrm{SH}$ and/or to the reduction of negative associative effects of NSC on ruminal digestion of fiber (Firkins, 1997; Titgemeyer, 2000). The mechanism by which feeding SH to replace grains in the diet caused a positive associative effect on fiber digestion remains unclear. Furthermore, there is a paucity of data describing the process of digestion of carbohydrate fractions other than fiber when $\mathrm{SH}$ are fed to dairy cows (Ipharraguerre and Clark, 2002).

Similar rates of substitution of SH for corn $(\leq 30 \%$ of dietary DM) supported ruminal synthesis of microbial protein (Cunningham et al., 1993; Mansfield and Stern, 1994) and apparent digestibility of $\mathrm{N}$ in the total gastrointestinal tract of dairy cows (Pantoja et al., 1994). On the other hand, there is only one study (Nakamura and Owen, 1989) reported in which the replacement of corn with SH exceeded $40 \%$ of the dietary DM. In that trial, Nakamura and Owen (1989) observed that the complete replacement of corn with $\mathrm{SH}$ (48\% of dietary DM) in diets that contained $50 \%$ forage and $50 \%$ concentrate reduced NSC concentration; increased ruminal turnover rate; and decreased milk production, milk protein output, nutrient digestion, and nutrient utilization by lactating dairy cows. However, lack of sufficient evidence from experiments in which $\mathrm{SH}$ constituted more than 25 to $30 \%$ of the dietary DM restricts any attempt to establish a maximum at which $\mathrm{SH}$ can be substituted for cereal grains so as to optimize the supply of nutrients for production of milk and milk components (Ipharraguerre and Clark, 2002).

The objectives of this study were: 1 ) to evaluate the effects of the incremental substitution of $\mathrm{SH}$ for ground corn in high grain diets on ruminal fermentation, site and extent of nutrient digestion, microbial protein synthesis, and passage of nutrients to the small intestine of lactating dairy cows; and 2) to relate differences in production of milk and milk components determined in a companion experiment (Ipharraguerre et al., 2002) to alterations in ruminal fermentation, passage of nutrients to the small intestine, and utilization of nutrients by dairy cows.

\section{MATERIALS AND METHODS}

\section{Animal Management, Experimental Design, and Diets}

Five multiparous Holstein cows that averaged $574 \pm$ $61 \mathrm{~kg}$ in BW and $63 \pm 12 \mathrm{DIM}$ at the onset of the experiment were surgically fitted with ruminal and duodenal cannulas according to procedures approved by the University of Illinois Laboratory Animal Care Advisory Committee. The ruminal cannulas were constructed of soft plastic (Bar Diamond, Parma, ID) and measured $10.2 \mathrm{~cm}$ in diameter. The duodenal cannulas were an enclosed T-shaped design made of stainless steel (Berzins Vet Laboratory LTD, Edmonton, Alberta, Canada). They were placed proximal to the common bile and pancreatic duct, about $10 \mathrm{~cm}$ distal to the pylorus.

Cows were housed in individual stanchions equipped with water bowls and bedded with straw. With the exception of the last $3 \mathrm{~d}$ of each period, cows were allowed to exercise in a drylot from 0800 to $0900 \mathrm{~h}$. Cows were fed a TMR for ad libitum intake and were milked daily at 0500 and $1700 \mathrm{~h}$. The experimental design was a 5 $\times 5$ Latin square with 14 -d periods. The first $9 \mathrm{~d}$ of each period were used to adapt the cows to treatments and the remaining $5 \mathrm{~d}$ were used to collect data. Each cow was randomly assigned to one of five treatment sequences in which a treatment never followed the same treatment for all sequences. The control diet contained $46 \%$ forage, $54 \%$ concentrate, and no SH. For the other four dietary treatments pelleted $\mathrm{SH}$ replaced corn in the concentrate to supply $10,20,30$, or $40 \%$ of the dietary DM (Table 1). All diets were formulated to contain $16 \% \mathrm{CP}$ and to meet the NRC (1989) recommendations for other nutrients. Diets were adjusted weekly to reflect changes in DM of forages and concentrate mixtures by drying each component overnight in an oven at $105^{\circ} \mathrm{C}$.

\section{Sampling, Measurements, and Analyses}

Dry matter intake and orts were measured and recorded daily. Samples of individual feed ingredients, TMR, and orts were collected for the last $5 \mathrm{~d}$ of each period. Samples of individual feedstuffs and TMR were dried at $55^{\circ} \mathrm{C}$ in an oven for $72 \mathrm{~h}$, ground through a 2$\mathrm{mm}$ screen in a Willy Mill (Arthur H. Thomas, Philadelphia, PA), composited on an equal weight basis by period, and ground through a $1-\mathrm{mm}$ screen. Samples of orts were dried at $55^{\circ} \mathrm{C}$ in an oven for $72 \mathrm{~h}$, ground through a 2-mm screen, composited by the amount and dry weight of the daily orts for each cow, and ground through a 1-mm screen. Samples of feeds, TMR, and orts were analyzed for DM, OM, Kjeldahl N (AOAC, 1990), ADF (Van Soest et al., 1991), NDF with heat- 
Table 1. Ingredient and chemical composition of the experimental diets.

\begin{tabular}{|c|c|c|c|c|c|}
\hline \multirow[b]{2}{*}{ Composition } & \multicolumn{5}{|c|}{ Soyhulls in diet, ${ }^{1} \%$} \\
\hline & 0 & 10 & 20 & 30 & 40 \\
\hline & & & $\%$ of $\mathrm{DI}$ & & \\
\hline \multicolumn{6}{|l|}{ Ingredient } \\
\hline Alfalfa silage & 23.00 & 23.00 & 23.00 & 23.00 & 23.00 \\
\hline Corn silage & 23.00 & 23.00 & 23.00 & 23.00 & 23.00 \\
\hline Soyhulls, pelleted & 0.00 & 10.00 & 20.00 & 30.00 & 40.00 \\
\hline Ground shelled corn & 40.32 & 30.48 & 20.75 & 10.88 & 1.00 \\
\hline Soybean meal, $49 \% \mathrm{CP}$ & 10.50 & 10.30 & 10.25 & 10.25 & 10.00 \\
\hline Sodium bicarbonate & 1.00 & 1.00 & 1.00 & 1.00 & 1.00 \\
\hline Sodium chloride & 0.25 & 0.25 & 0.25 & 0.25 & 0.25 \\
\hline Dicalcium phosphate & 0.50 & 0.60 & 0.70 & 0.80 & 0.90 \\
\hline Limestone & 0.63 & 0.55 & 0.22 & 0.00 & 0.00 \\
\hline Mineral and vitamin $\operatorname{mix}^{2}$ & 0.25 & 0.25 & 0.25 & 0.25 & 0.25 \\
\hline Magnesium oxide & 0.20 & 0.20 & 0.18 & 0.15 & 0.15 \\
\hline Sodium sulfate & 0.35 & 0.37 & 0.40 & 0.42 & 0.45 \\
\hline \multicolumn{6}{|l|}{ Chemical } \\
\hline DM & 59.2 & 59.0 & 59.1 & 59.3 & 58.6 \\
\hline $\mathrm{OM}$ & 93.0 & 92.8 & 92.7 & 92.6 & 92.2 \\
\hline $\mathrm{CP}$ & 15.0 & 15.3 & 15.6 & 16.0 & 16.3 \\
\hline $\mathrm{NDF}$ & 26.6 & 30.4 & 35.9 & 40.8 & 45.4 \\
\hline $\mathrm{ADF}$ & 16.8 & 21.0 & 24.6 & 29.0 & 32.5 \\
\hline $\mathrm{NSC}$ & 35.9 & 29.7 & 25.3 & 20.9 & 15.6 \\
\hline $\mathrm{NE}_{\mathrm{L}}, \mathrm{Mcal} / \mathrm{kg}$ of $\mathrm{DM}^{3}$ & 1.66 & 1.60 & 1.55 & 1.50 & 1.44 \\
\hline
\end{tabular}

stable $\alpha$-amylase (Thermamyl 120L, Novo Nordisk Biochem, Franklinton, NC) and sodium sulfite (Van Soest et al., 1991), and NSC according to the enzymatic method of Smith (1981). Samples of feeds and TMR were prepared for AA determination, except Met, by acid hydrolysis with $6 \mathrm{~N} \mathrm{HCl}$ (McCarthy et al., 1989). For Met determination, samples were first oxidized with performic acid, lyophilized after dilution with water to remove excess performic acid (Overton et al., 1995), and hydrolyzed with $6 \mathrm{~N} \mathrm{HCl}$ as outlined by Moore (1963). Individual AA were then separated by ion exchange chromatography on a Beckman 126AA amino acid analyzer equipped with a Beckman 12-cm column (Beckman Instruments Inc., Palo Alto, CA).

Samples of ruminal fluid and duodenal digesta were collected every $3 \mathrm{~h}$ during the last $3 \mathrm{~d}$ of each period. The sampling time was adjusted ahead $1 \mathrm{~h}$ daily so that a sample was obtained for each 1-h interval of the day (24 total samples). Ruminal fluid samples were taken from multiple sites in the rumen and $\mathrm{pH}$ of ruminal fluid was measured immediately by glass electrode. After measurement of $\mathrm{pH}$, a subsample of $50 \mathrm{ml}$ was acidified to $\mathrm{pH}<2$ with $50 \% \mathrm{H}_{2} \mathrm{SO}_{4}(\mathrm{v} / \mathrm{v})$, centrifuged at $27,000 \times g$ for $10 \mathrm{~min}$ at $4^{\circ} \mathrm{C}$, and the supernatant was frozen at $-20^{\circ} \mathrm{C}$ for later analyses. Following removal of the cap of the duodenal cannula, accumulated digesta was discarded, and when the flow appeared normal 500 $\mathrm{ml}$ of duodenal contents were collected. The volume of sample collected represented less than $4 \%$ of the estimated passage of digesta to the duodenum during the three days of collection. Samples were pooled by cow and stored frozen in $20 \mathrm{~L}$ buckets at $-20^{\circ} \mathrm{C}$ until analyses.

After thawing, ruminal fluid samples were centrifuged at $27,000 \times g$ for $20 \mathrm{~min}$ at $4^{\circ} \mathrm{C}$ and an aliquot of $4 \mathrm{ml}$ was diluted with $25 \%$ metaphosphoric acid (4:1 ratio). These subsamples were used to determine VFA with a gas chromatograph (model 5890 Series II; Hewlett-Packard, Avondale, PA) equipped with a $1.8 \mathrm{~m}$ glass column packed with $10 \%$ SP $1200 / 1 \% \mathrm{H}_{3} \mathrm{PO}_{4}$ on $80 / 100$ chromosorb W AW (Supelco, 1975). Nitrogen was the carrier gas and the temperature of the injector port and column was $175^{\circ} \mathrm{C}$ and $125^{\circ} \mathrm{C}$, respectively. Ruminal $\mathrm{NH}_{3} \mathrm{~N}$ was determined according to the procedures outlined by Chaney and Marbach (1962) as modified by Cotta and Russell (1982).

Duodenal samples were thawed and homogenized for 5 min using a propeller-type mixer set at high speed. During continuous stirring, a representative subsample $(1000 \mathrm{ml})$ of digesta was collected by vacuum. Samples then were poured into shallow pans, lyophilized, ground through a 1-mm screen, and analyzed for DM, OM, Kjeldhal N, ADF, NDF, NSC, and AA as described above. The duodenal content of $\mathrm{NH}_{3} \mathrm{~N}$ was determined 
by steam distillation with $\mathrm{MgO}$ (Bremner and Keeney, 1965) and purines, used as a bacterial marker, were measured by the method of Zinn and Owens (1986).

Ruminal bacteria were isolated from samples (1000 $\mathrm{ml}$ ) of whole ruminal contents obtained from the reticulum near the reticulo-omasal orifice at six separate postfeeding times $(0,2,4,6,8$, and $10 \mathrm{~h})$ during the last $3 \mathrm{~d}$ of each period. Ruminal contents were blended in a Waring blender (Waring Products Division, New Hartford, CT) for $1 \mathrm{~min}$ at low speed, strained through six layers of cheesecloth, and the effluents were used to prepare a bacteria-rich sample by differential centrifugation (Overton et al., 1995). Bacterial samples were pooled by cow within period and frozen at $-20^{\circ} \mathrm{C}$. These samples were lyophilized and analyzed for DM, OM, Kjeldhal N, AA, and purines by the methods described above.

During the last $5 \mathrm{~d}$ of each period, fecal grab samples were collected at 0700 and $1900 \mathrm{~h}$, composited on an equal wet weight basis, dried at $55^{\circ} \mathrm{C}$, ground through a 1-mm screen, and assayed for DM, OM, Kjeldhal N, $\mathrm{ADF}, \mathrm{NDF}$, and NSC as described above.

Chromic oxide $\left(\mathrm{Cr}_{2} \mathrm{O}_{3}\right)$ was used as an indigestible marker to assess the passage of digesta to the duodenum and fecal excretion by the cows. Gelatin capsules that contained $10 \mathrm{~g}$ of $\mathrm{Cr}_{2} \mathrm{O}_{3}$ powder were administered via the ruminal cannula at 0800 and $2000 \mathrm{~h}$ during the last $10 \mathrm{~d}$ of each period. Concentration of $\mathrm{Cr}$ in duodenal and fecal samples was quantified by atomic absorption spectroscopy (air plus acetylene flame; Perkin-Elmer, Norwalk, CT) after preparation of samples by the procedure of Williams et al. (1962).

Passage of microbial $\mathrm{N}$ and $\mathrm{OM}$ to the duodenum was calculated from the passage of DM and from the proportion of $\mathrm{N}$ or $\mathrm{OM}$ of bacterial origin, respectively. These proportions were estimated by dividing the $\mathrm{N}$ to purine ratio or the OM to purine ratio of isolated bacteria by the $\mathrm{N}$ to purine ratio or the $\mathrm{OM}$ to purine ratio of duodenal digesta. Passage of nonammonia nonmicrobial N (NANMN) to the duodenum was calculated by subtracting passage of microbial $\mathrm{N}$ from passage of total NAN. Apparent digestibility of OM in the rumen was corrected for the passage of microbial OM to the duodenum to establish the amount of OM truly digested in the rumen.

Milk weights were recorded at each milking throughout the last $7 \mathrm{~d}$ of each period. Milk samples were taken at each milking during the last $7 \mathrm{~d}$ of each period, preserved with 2-bromo-2-nitropropane-1,3-diol, and stored at $4^{\circ} \mathrm{C}$. Samples were sent to Dairy One Cooperative Inc. (Ithaca, NY) for analyses of fat, CP, true protein, total solids, and milk urea N (MUN) by infrared procedures (Foss 4000; Foss North America, Eden Prairie, $\mathrm{MN})$.

\section{Statistical Analyses}

Data were analyzed using the MIXED procedure of SAS (2000), with cow treated as a random variable. With the exception of ruminal variables, data were analyzed as a $5 \times 5$ Latin square with the following model:

$$
\boldsymbol{Y}_{\mathrm{ijk}}=\boldsymbol{\mu}+\boldsymbol{C}_{\mathrm{i}}+\boldsymbol{P}_{\mathrm{j}}+\boldsymbol{T}_{\mathrm{k}}+\varepsilon_{\mathrm{ijk}}
$$

where:

$$
\begin{aligned}
\mu & =\text { overall mean } \\
\mathrm{C}_{\mathrm{i}} & =\text { effect of cow } \mathrm{i}(\mathrm{i}=1,2,3,4,5), \\
\mathrm{P}_{\mathrm{j}} & =\text { effect of period } \mathrm{j}(\mathrm{j}=1,2,3,4,5), \\
\mathrm{T}_{\mathrm{k}} & =\text { effect of treatment } \mathrm{k}(\mathrm{k}=1,2,3,4,5), \text { and } \\
\varepsilon_{\mathrm{ijk}} & =\text { residual error. }
\end{aligned}
$$

The degrees of freedom for treatment were partitioned into four single-degree-of-freedom non-orthogonal contrasts: linear, quadratic, $\mathrm{SH}$ diets vs. control diet, and 40\% SH diet vs. control diet. Linear and quadratic contrasts included the control and all $\mathrm{SH}$ diets.

Ruminal VFA, $\mathrm{NH}_{3} \mathrm{~N}$, and $\mathrm{pH}$ data were analyzed using the repeated measures approach of the MIXED procedure of SAS (Littell et al., 1996). Based on the largest value for the Akaike's information criterion (Littell et al., 1996), the compound symmetric structure type was selected as the appropriate covariance structure. The model was similar to the model described previously except for the addition of the effect of hour and the interaction of treatment and hour. Because the treatment by hour interaction was not significant $(P>$ 0.05 ) for the ruminal parameters measured, treatment effects were compared across treatment sampling times using the contrasts described above.

Differences among treatments were considered to be significant when $P<0.05$, whereas when $P>0.05$ but $<0.10$ differences were considered to indicate a trend towards a significant effect.

During the third period, one cow had abnormally low DMI and diarrhea because of heat stress. Veterinarians of the Ambulatory Service at the University of Illinois hydrated this cow with an electrolytic solution via the ruminal cannula and allowed her to recover during that period. Therefore, samples from that cow were not collected during the third period.

\section{RESULTS AND DISCUSSION}

\section{Composition of Experimental Diets}

The ingredient and chemical composition of diets is shown in Table 1. As expected, the incremental substitution of SH for corn markedly increased NDF and ADF in the diet. In contrast, as the percentage of $\mathrm{SH}$ in the 
Table 2. Chemical composition of forages and soyhulls fed in the experimental diets.

\begin{tabular}{llll}
\hline Item & $\begin{array}{l}\text { Corn } \\
\text { silage }\end{array}$ & $\begin{array}{l}\text { Alfalfa } \\
\text { silage }\end{array}$ & Soyhulls \\
\cline { 2 - 3 } & & $\%$ of DM $)$ & \\
CP & 8.0 & 23.4 & 11.9 \\
NDF & 38.2 & 37.5 & 67.2 \\
ADF & 22.0 & 29.8 & 46.9 \\
NSC & 33.6 & 8.2 & 12.8 \\
\hline
\end{tabular}

diets increased up to $40 \%$, the concentration of NSC decreased by about $57 \%$. These differences resulted because of the chemical composition of SH that are high in fiber and low in other carbohydrate fractions, such as NSC (Table 2; NRC, 2001). The CP percentage of the diets increased as additional increments of pelleted $\mathrm{SH}$ were substituted for corn (Table 1). The increase in $\mathrm{CP}$ content of the diets occurred because the $\mathrm{CP}$ content of the pelleted $\mathrm{SH}$ was slightly greater than expected and the CP content of corn was slightly lower. All diets, however, met or exceeded the requirements (NRC, 2001) for CP, RUP, and RDP of cows used in this experiment.

\section{Intakes and Digestibilities of DM and OM}

The average intake of DM for all treatments was $21.6 \mathrm{~kg} / \mathrm{d}$, and differences among treatments were not significant (Table 3 ). In a companion experiment (Ipharraguerre et al., 2002), however, DMI of midlactation dairy cows decreased linearly $(P<0.06)$ as incremental additions of $\mathrm{SH}$ were substituted for corn. Similar trends for DMI by cows in early lactation also were observed when SH replaced about $14 \%$ of the total DM in the diet supplied as high moisture corn (Stone, 1996). In contrast, the use of $\mathrm{SH}$ as a cereal grain replacement in diets of dairy cattle failed to alter DMI when SH provided less than $35 \%$ of the total DM in the diet (Sarwar et al., 1992).

The percentage of DM apparently digested in the total gastrointestinal tract was unaffected by dietary treatments (Table 3). However, compared with the control diet, feeding the diet that contained $40 \% \mathrm{SH}$ tended to depress the amount of DM digested in the total tract by $1.6 \mathrm{~kg} / \mathrm{d}$. In an earlier study (Nakamura and Owen, 1989), the largest decrease in apparent DM digestibility in the total tract (i.e. nine percentage units) occurred when SH replaced corn to supply $48 \%$, but not $25 \%$, of the total dietary DM. Because in our experiment the percentage of DM digested did not change significantly, the decrease in the amount of DM digested can be attributed, at least partially, to the numerically lower DMI of cows fed the $40 \%$ SH diet.
The average intake of $\mathrm{OM}$ for all treatments was $20.0 \mathrm{~kg} / \mathrm{d}$ and differences among treatments were not significant (Table 3). The amount of OM apparently and truly digested in the rumen was unaffected by the feeding of diets that contained SH. However, the percentage of OM intake that was apparently or truly digested in the rumen tended to be higher for the $40 \% \mathrm{SH}$ diet compared with the control diet (Table 3). Mansfield and Stern (1994) reported that similar amounts and proportions of OM intake were apparently and truly digested in the rumen of lactating dairy cows fed diets in which SH replaced corn to supply $30 \%$ of the total DMI. To our knowledge, experiments that aimed to assess the site of nutrient digestion in dairy cows fed diets that contained more than $30 \% \mathrm{SH}$ (DM basis) have not been conducted.

The amount of OM that passed to and was digested in the intestines decreased significantly for diets that contained SH. Compared with the control diet, the diet that contained $40 \% \mathrm{SH}$ significantly decreased OM digestibility as a percentage of OM intake and tended to decrease $\mathrm{OM}$ digestibility as a percentage of OM that passed to the small intestine. The amount and the percentage of $\mathrm{OM}$ apparently digested in the total gastrointestinal tract were not affected by treatments. These results support previous findings, which indicate that replacing 12 to $34 \%$ of the total DM in the diet supplied as cereal grains with $\mathrm{SH}$, does not affect digestibility of OM in the total gastrointestinal tract (Sarwar et al., 1992; Cunningham et al., 1993).

DMI, rate of passage from the rumen, and the supply of NSC in relation to fiber from $\mathrm{SH}$ are at least three factors that might explain why there were differences in digestibility of $\mathrm{OM}$ in the rumen and intestines, but not in the total tract. Nakamura and Owen (1989) reported that the replacement of corn with $\mathrm{SH}$ to supply 25 and $48 \%$ of the total dietary DM did not affect DMI, but enhanced the rate of passage of $\mathrm{SH}$ and decreased the proportion of DM apparently digested in the total tract. Because starch from corn has a similar or even slower (3.6 to 4.0\%/h; Nocek and Tamminga, 1991) rate of ruminal disappearance than fiber from $\mathrm{SH}$ (3.3 to $10.3 \% / \mathrm{h}$; Ipharraguerre and Clark, 2002), it is possible that ruminal turnover rate might have increased as $\mathrm{SH}$ were increased in the diet, decreasing ruminal digestibility of OM when $\mathrm{SH}$ provided $30 \%$ or less of the dietary DM. In contrast, when SH provided $40 \%$ of the dietary DM the numerically lower intake of OM might have offset any increase in the rate of passage, in turn improving OM digestibility in the rumen. These observations are in agreement with other findings (Cunningham et al., 1993; Feng et al, 1993), indicating that ruminal fermentation of OM might be maintained or even improved if dietary NSC are reduced by replacing cereal 
Table 3. Least squares means for intakes and digestibilities of DM and OM in various segments of the gastrointestinal tract of lactating dairy cows fed diets containing incremental amounts of soyhulls.

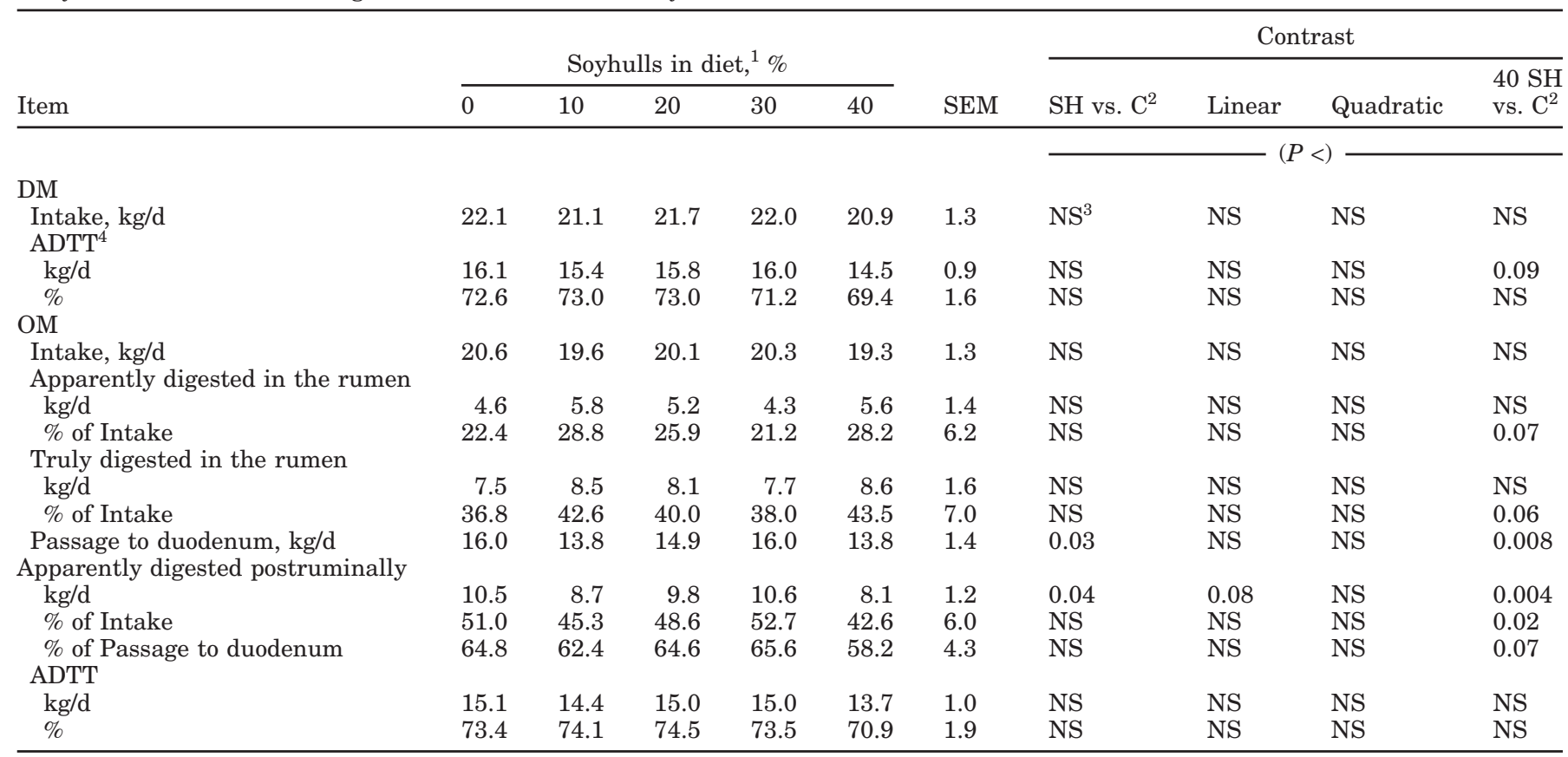

${ }^{1}$ Soyhulls were substituted for corn in the experimental diets.

${ }^{2} \mathrm{SH}$ vs. $\mathrm{C}=$ Soyhull diets vs. control diet, $40 \mathrm{SH}$ vs. $\mathrm{C}=40 \%$ soyhull diet vs. control diet.

${ }^{3}$ Nonsignificant $(P>0.10)$.

${ }^{4}$ Apparently digested in the total gastrointestinal tract.

grains with fermentable nonforage fiber sources in the diet.

\section{Intakes and Digestibilities of NSC}

The intake of NSC decreased linearly as SH replaced corn in the diet, being $4.8 \mathrm{~kg} / \mathrm{d}$ per cow greater for the control diet compared with the diet that contained $40 \%$ $\mathrm{SH}$ (Table 4). The linear decrease in intake of NSC was caused mainly by the decreasing concentration of NSC in the diets (Table 1) when SH replaced corn. Other researchers also reported a lower intake of NSC (Feng et al., 1993; Mansfield and Stern, 1994) from diets in which the percentage of NSC was altered by varying the dietary concentration of fibrous byproducts and cereal grains.

The amount and percentage of NSC apparently digested in the rumen decreased linearly as $\mathrm{SH}$ were substituted for corn (Table 4). Previous data indicate that reduced intake of NSC can depress the amount (Stokes et al., 1991) or both the amount and percentage (Feng et al., 1993) of NSC fermented in the rumen.

Because the content of starch in SH normally is negligible (NRC, 2001), we expect that as corn grain was removed from the diets the proportion of total NSC intake supplied as starch may have decreased progres- sively and markedly. This implies that a proportionally greater intake of NSC from carbohydrate sources other than starch must have occurred as $\mathrm{SH}$ partially replaced corn in the diet. These sources of carbohydrates were probably simple sugars and pectin, because $\mathrm{SH}$ contain high concentrations of these constituents. Simple sugars and pectin are degraded in the rumen at a faster rate than starch (Mertens, 1992). Even though SH contain these rapidly degradable simple sugars and pectin, there was a tendency for decreased ruminal digestibility of NSC in the diets that contained SH. This trend for decreased ruminal digestibility of NSC for the diets that contained $\mathrm{SH}$ might have occurred because of a faster rate of passage of $\mathrm{SH}$ than corn from the rumen. These observations are consistent with other findings (Lykos et al., 1997), which indicate that diets formulated to contain NSC with different rates of ruminal degradability $(6.04,6.98$, and $7.94 \% / \mathrm{h})$ did not differ among treatments for apparent ruminal digestibility of NSC because of different rates of passage of the NSC sources from the rumen.

The decreased intakes of NSC resulted in smaller quantities of these carbohydrates passing to the small intestine of cows fed diets that contained $\mathrm{SH}$, even though their ruminal digestibilities were depressed (Table 4). Once in the lower digestive tract, the amount 
Table 4. Least squares means for intakes and digestibilities of NSC in various segments of the gastrointestinal tract of lactating dairy cows fed diets containing different amounts of soyhulls.

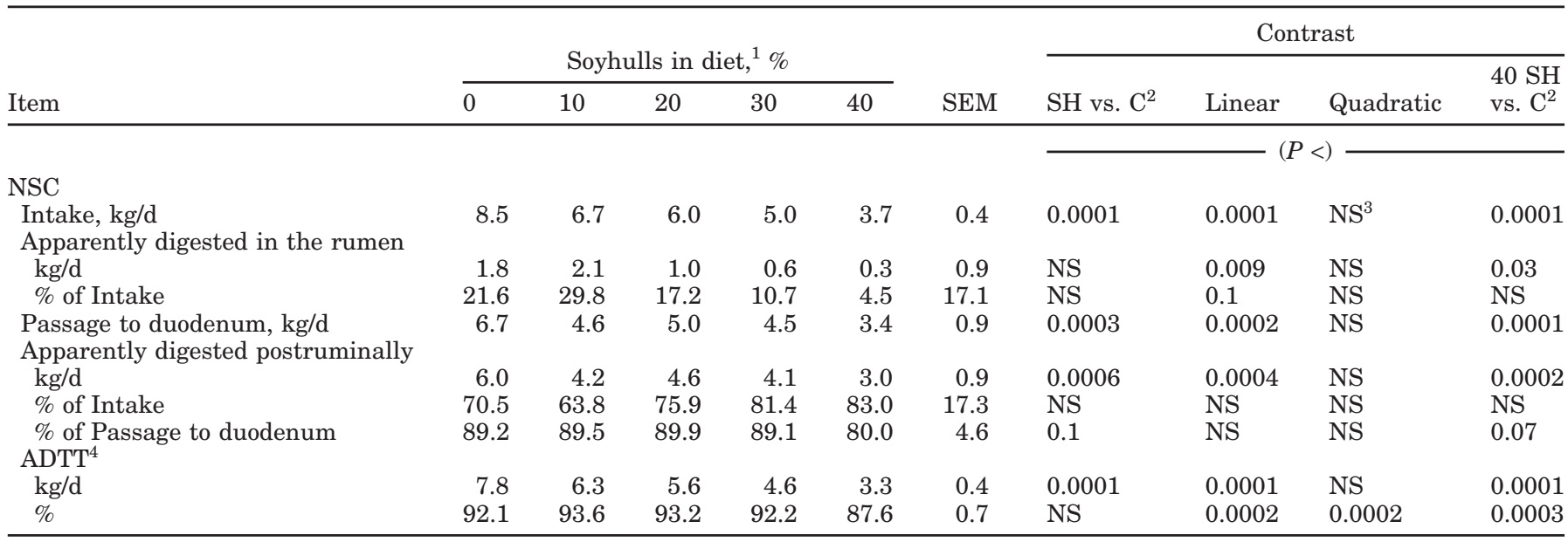

${ }^{1}$ Soyhulls were substituted for corn in the experimental diets.

${ }^{2} \mathrm{SH}$ vs. $\mathrm{C}=$ Soyhull diets vs. control diet, $40 \mathrm{SH}$ vs. $\mathrm{C}=40 \%$ soyhull diet vs. control diet.

${ }^{3} \mathrm{NS}=$ Nonsignificant $(P>0.10)$.

${ }^{4}$ Apparently digested in the total gastrointestinal tract.

of NSC apparently digested was greater for cows fed corn and decreased linearly as SH replaced corn in the diet. Mansfield and Stern (1994) reported that replacing ground corn with SH to supply $30 \%$ of the total dietary DM significantly reduced the amount of NSC passing to and digested in the small intestine.

In our experiment, the NSC digestibility as percentage of passage to duodenum tended to decrease when $\mathrm{SH}$ were fed, being about nine percentage units lower for the diet that contained $40 \% \mathrm{SH}$ than for other treatments (Table 4). The depressed postruminal digestibility of NSC probably occurred because the proportions of highly digestible NSC that would be fermented in the rumen increased as SH replaced corn in the diet, leaving a proportionally larger fraction of less digestible NSC that was more likely to escape postruminal digestion. Recent data of Lykos et al. (1997) indicate that postruminal digestibility of NSC in dairy cows was increased almost four-fold when similar amounts of NSC with dissimilar rates of ruminal degradability passed to the lower digestive tract.

The quantity of NSC apparently digested in the total tract declined with the incremental substitution of $\mathrm{SH}$ for corn in the diets (Table 4), which was caused largely by the lower intake of these carbohydrate fractions when cows were fed $\mathrm{SH}$. The substitution of $\mathrm{SH}$ for corn in the diet resulted in a quadratic response for digestibility of NSC in the total digestive tract when expressed as a percentage of intake, which was lowest for the diet that contained $40 \% \mathrm{SH}$. The largest depression in digestibility was obtained for the diet that contained $40 \% \mathrm{SH}$ and occurred because of a lower intake and decreased digestibility in both the rumen and lower digestive tract.

Digestibilities of NSC were lower in the rumen and were higher in the lower digestive tract than values previously reported for diets that contained similar concentrations of NSC (Stokes et al., 1991; Feng et al., 1993; Mansfield and Stern, 1994; Lykos et al., 1997), in which corn was the predominant source of NSC. Potential sources of variation that might explain these discrepancies include decreasing precision of the methodology used in the determination of NSC as their concentration in the collected samples decreased to low levels, especially for the samples from the treatment that contained $40 \% \mathrm{SH}$, and/or segregation of digesta particles, particularly pieces of corn kernel that were high in starch, during sampling, processing, or both.

\section{Intakes and Digestibilities of ADF and NDF}

Intakes of $\mathrm{ADF}$ and $\mathrm{NDF}$ were smallest for cows fed the control diet and increased linearly in response to the incremental substitution of SH for corn (Table 5). These responses were obtained because of the higher concentration of $\mathrm{ADF}$ and $\mathrm{NDF}$ in the $\mathrm{SH}$ diets (Table 1), which agree with results from other experiments in which SH were added to the diet without the diets being made equal in fiber (Cunningham et al., 1993; Ipharraguerre et al., 2002).

The quantities of $\mathrm{ADF}$ and NDF fermented in the rumen, passed to the duodenum, digested in the lower tract, and digested in the total tract were greater for cows fed $\mathrm{SH}$ than for cows fed the control diet and 
Table 5. Least squares means for intakes and digestibilities of ADF and NDF in various segments of the gastrointestinal tract of lactating dairy cows fed diets containing different amounts of soyhulls.

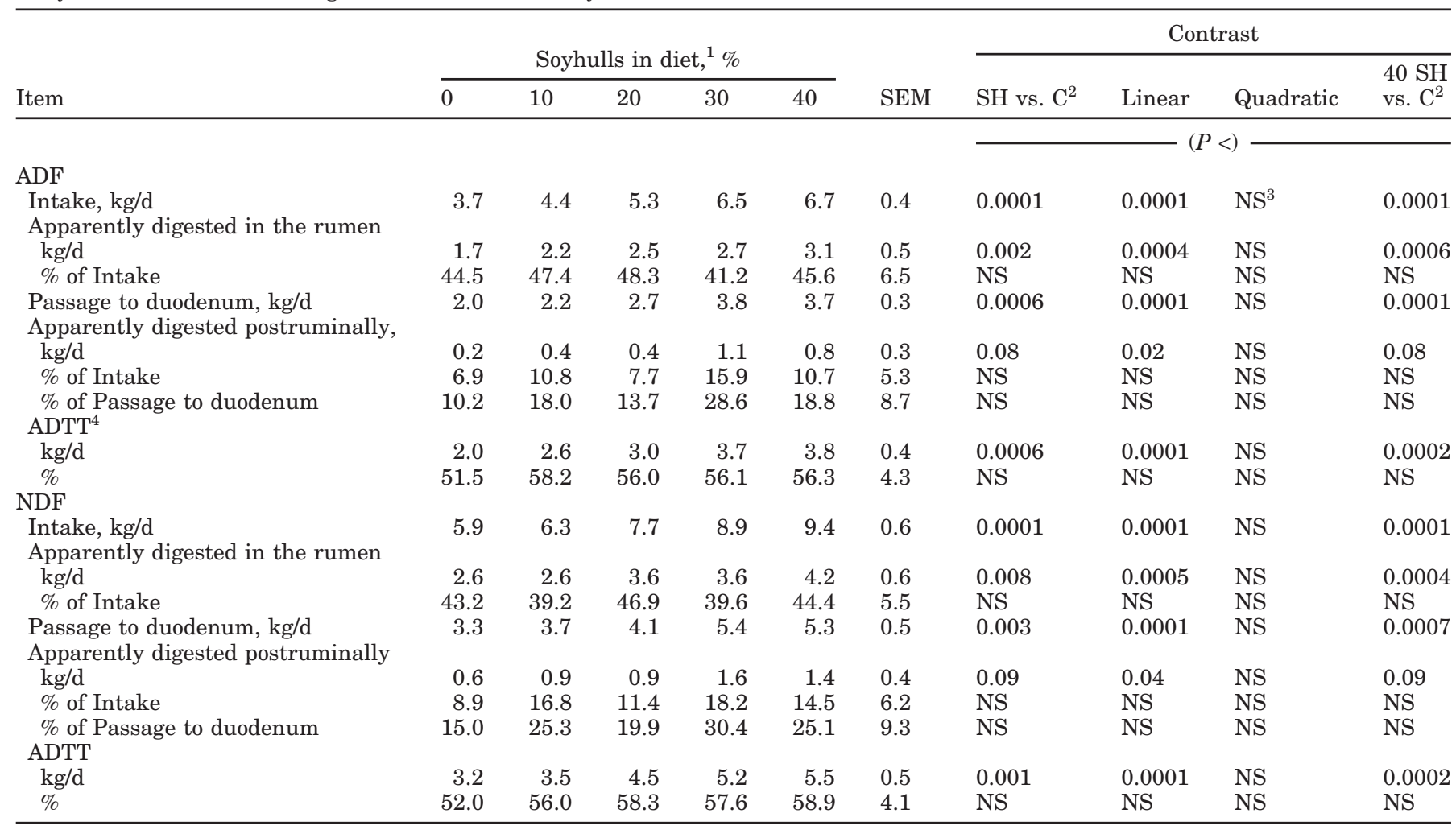

${ }^{1}$ Soyhulls were substituted for corn in the experimental diets.

${ }^{2} \mathrm{SH}$ vs. $\mathrm{C}=$ Soyhull diets vs. control diet, $40 \mathrm{SH}$ vs. $\mathrm{C}=40 \%$ soyhull diet vs. control diet.

${ }^{3} \mathrm{NS}=$ Nonsignificant $(P>0.10)$.

${ }^{4}$ Apparently digested in the total gastrointestinal tract.

increased linearly as additional $\mathrm{SH}$ replaced corn in the diet (Table 5). Cunningham et al. (1993) and Mansfield and Stern (1994) also reported that large intakes of NDF that resulted from the replacement of corn with $\mathrm{SH}$ in diets for dairy cows ( $\geq 50 \%$ concentrate) enhanced the amount of NDF apparently digested in the rumen and total digestive tract. However, the passage of NDF to the duodenum increased significantly only when $30 \%$ of the dietary DM (Mansfield and Stern, 1994), but not $25 \%$ or less (Cunningham et al., 1993), was supplied from $\mathrm{SH}$.

The proportions of $\mathrm{ADF}$ and NDF that were apparently digested in the rumen as a percentage of intake, digested in the lower tract as a percentage of intake and as a percentage of passage to the duodenum, and digested in the total digestive tract were similar among treatments (Table 5). Inclusion of SH in diets for dairy cows increased ruminal digestibility of NDF in one experiment (Cunningham et al., 1993) but failed to affect it in another (Mansfield and Stern, 1994). Apparent digestibility of $\mathrm{NDF}$ in the total digestive tract of lactating cows was numerically (Nakamura and Owen, 1989) or significantly (Cunningham et al., 1993; Pantoja et al., 1994) improved when $\mathrm{SH}$ replaced cereal grains (SH ranged from 12 to $48 \%$ of dietary DM) in the diet. Compared with the control diet, the average increase in digestibility of NDF in the total tract for diets that contained SH was $11 \%$ (Table 5), which is in close agreement with the $14 \%$ improvement estimated by Firkins (1997). Firkins (1997) suggested that the replacement of concentrate with sources of nonforage fiber might have positive associative effects on fiber digestibility but only when the NFC concentration of the control diet was equal to or greater than $45 \%$; moreover, the largest response in digestibility occurred when the reduction in NFC of the control diet was from 45 to $35 \%$. Therefore, in our trial, the highest concentration of readily fermentable carbohydrates (35.9\% NSC) might already be too low to negatively affect ruminal fiber digestibility, which might explain why NDF digestibilities were similar for all dietary treatments. Additionally, an accelerated rate of ruminal outflow for diets that contain large quantities of $\mathrm{SH}$ might also have contributed to equalize NDF digestibilities among 
Table 6. Least squares means for ruminal characteristics of lactating dairy cows fed diets containing different amounts of soyhulls.

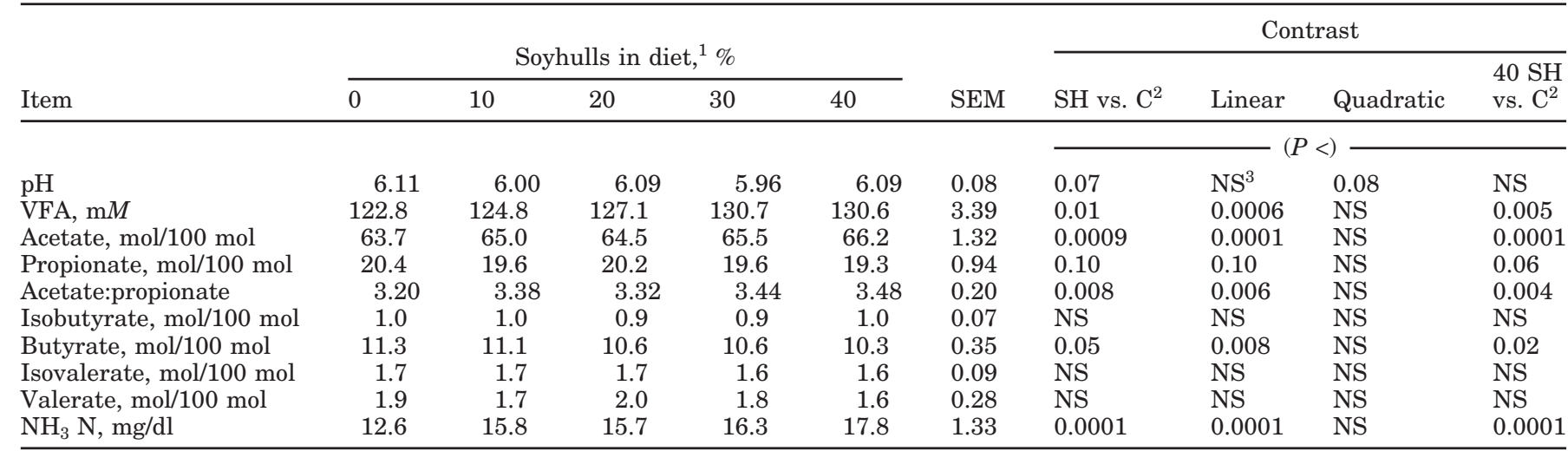

${ }^{1}$ Soyhulls were substituted for corn in the experimental diets.

${ }^{2} \mathrm{SH}$ vs. C $=$ Soyhull diets vs. control diet, $40 \mathrm{SH}$ vs. $\mathrm{C}=40 \%$ soyhull diet vs. control diet.

${ }^{3} \mathrm{NS}=$ Nonsignificant $(P>0.10)$.

treatments, as was suggested by Nakamura and Owen (1989).

\section{Ruminal Environment}

Ruminal $\mathrm{pH}$ tended to decrease when $\mathrm{SH}$ partially replaced corn in the diet, and replacing incremental quantities of corn with $\mathrm{SH}$ resulted in a trend for a quadratic decrease in $\mathrm{pH}$ (Table 6); however, these effects probably were not biologically significant. Generally, the use of SH as a replacement for grain has not altered ruminal pH (Mansfield and Stern, 1994; Elliott et al., 1995) but, in some trials, numerical trends similar to those in our trial were observed (Cunningham et al., 1993; Pantoja et al., 1994). In part, this effect could be associated with the amount of NSC in the diets fed in our experiment, which might be less than the quantity required to induce major changes in the environment of the rumen (Nocek, 1997). Sarwar et al. (1992) reported that reducing NSC in the diet from 50 to 37 and $27 \%$ through partial substitution of $\mathrm{SH}$ for corn in diets that contained 57\% concentrate decreased the characteristic postfeeding decline in ruminal $\mathrm{pH}$, although the decline was only significant at $9 \mathrm{~h}$ postfeeding.

The concentration of VFA in ruminal fluid was lowest when the control diet was fed and increased linearly as corn was replaced with $\mathrm{SH}$ (Table 6). These findings agree with data from a number of studies (Cunningham et al., 1993; Mansfield and Stern, 1994; Pantoja et al., 1994), reflecting the highly fermentable nature of fiber in SH. As SH were substituted for corn at incremental rates, the molar proportion of acetate increased and that of propionate tended to decline, resulting in a significantly higher acetate-to-propionate ratio (Table 6). Ruminal fluid from cows fed the control diet had the highest concentration of butyrate, and increasing the amount of SH in the diet linearly reduced the molar percentage of butyrate, but the molar percentages of isobutyrate, isovalerate, and valerate were not affected by treatments (Table 6). Similar alterations in the pattern of VFA in ruminal fluid have been reported when SH partially or totally replaced cereal grains in diets of dairy cattle (Sarwar et al., 1991; 1992) and beef cattle (Grigsby et al., 1993). Mansfield and Stern (1994) suggested that such changes in the molar proportions of ruminal VFA reveal a shift in the type of carbohydrate (NSC vs. fiber) being fermented in the rumen. This interpretation of the VFA concentrations agrees with our data because as the amount of corn replaced with SH increased from 0 to $40 \%$ the amount of NSC digested in the rumen declined by about $83 \%$ (Table 4 ) and the amount of NDF digested increased by approximately $62 \%$ (Table 5). Even though the changes in digestibility of NSC and NDF were rather large and the changes in total concentrations and molar proportions of VFA were significantly different, the magnitude of the changes in concentrations and molar proportions of VFA was small and changes probably were not biologically significant. The molar proportion of propionate and the acetate to propionate ratio were in the range for the production of milk with a normal fat content (Erdman, 1988).

The concentration of $\mathrm{NH}_{3} \mathrm{~N}$ in ruminal fluid was greater for cows fed $\mathrm{SH}$ than for cows fed corn and increased linearly from 12.6 to $17.8 \mathrm{mg} / \mathrm{dl}$ as increments of SH replaced corn in the diet (Table 6). This linear increase in $\mathrm{NH}_{3} \mathrm{~N}$ probably occurred because the $\mathrm{CP}$ concentration of the diet increased as $\mathrm{SH}$ replaced corn (Table 1). Partial replacement of cereal grains with $\mathrm{SH}$ in diets of dairy cows has depressed concentrations of $\mathrm{NH}_{3} \mathrm{~N}$ in ruminal fluid in two trials (Mansfield and Stern, 1994; Sarwar et al., 1992) but had no effect in another experiment (Cunningham et al., 1993). In our 
Table 7. Least squares means for intake and digestibility of $\mathrm{N}$ in various segments of the gastrointestinal tract of lactating dairy cows fed diets containing different amounts of soyhulls.

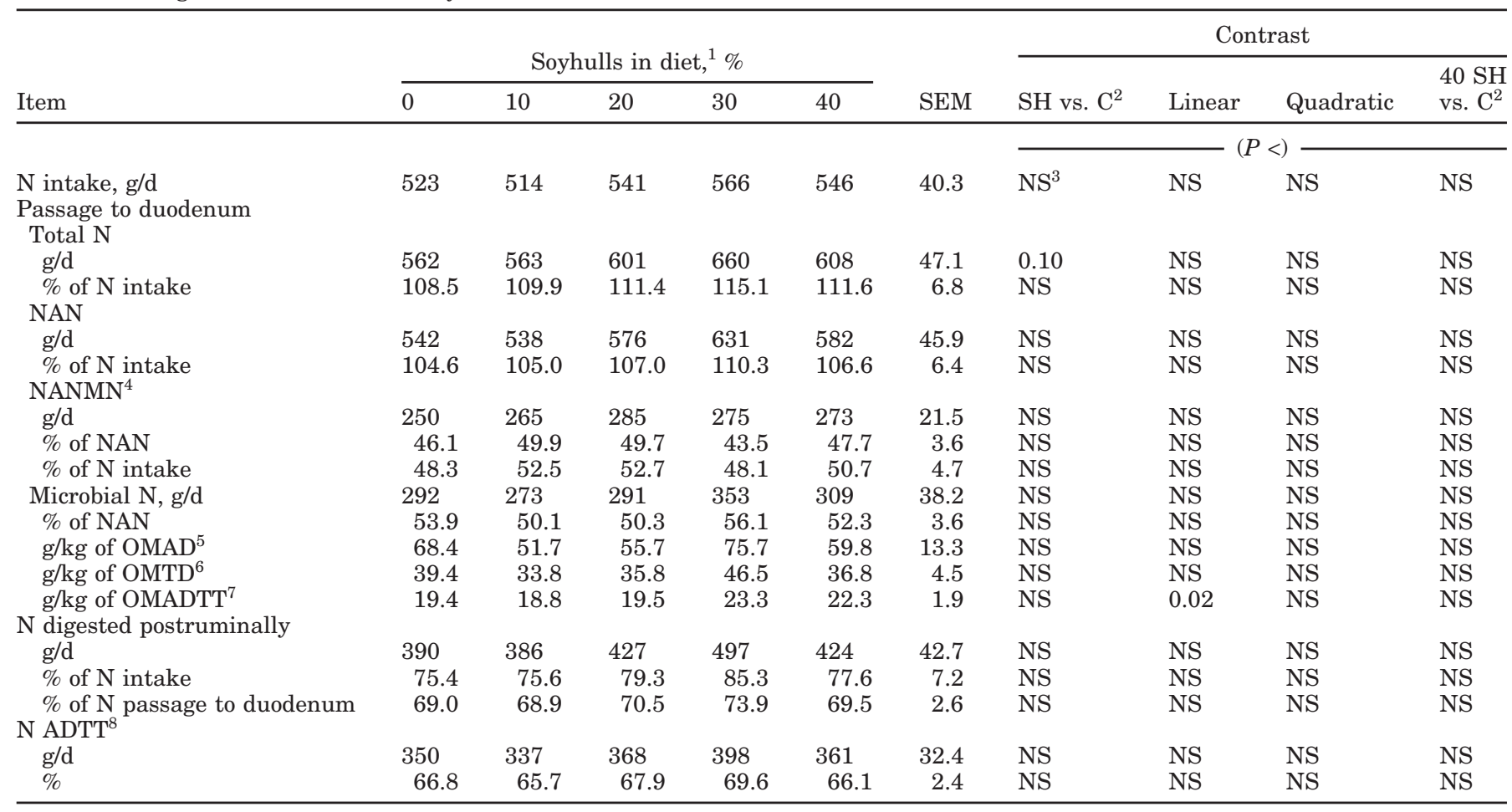

${ }^{1}$ Soyhulls were substituted for corn in the experimental diets.

${ }^{2} \mathrm{SH}$ vs. $\mathrm{C}=$ Soyhull diets vs. control diet, $40 \% \mathrm{SH}$ vs. $\mathrm{C}=40 \%$ soyhull diet vs. control diet.

${ }^{3} \mathrm{NS}=$ Nonsignificant $(P>0.10)$.

${ }^{4}$ Nonammonia nonmicrobial $\mathrm{N}$.

${ }^{5}$ Organic matter apparently digested in the rumen.

${ }^{6}$ Organic matter truly digested in the rumen.

${ }^{7}$ Organic matter apparently digested in the total gastrointestinal tract.

${ }^{8}$ Apparently digested in the total gastrointestinal tract.

experiment and in these cited experiments, the concentration of $\mathrm{NH}_{3} \mathrm{~N}$ in ruminal fluid from cows fed all diets was greater than the minimum concentration of $5 \mathrm{mg} /$ dl recommended for maximum microbial growth (Satter and Slyter, 1974). These data suggest that there was not a deficiency of $\mathrm{NH}_{3} \mathrm{~N}$ in ruminal fluid for maximizing microbial protein synthesis.

\section{Nitrogen Intake and Metabolism}

The intake of $\mathrm{N}$ was similar among treatments, averaging $538 \mathrm{~g} / \mathrm{d}$ per cow for all diets (Table 7). The amount of total $\mathrm{N}$ that passed to the duodenum tended to be greater for cows fed diets that contained $\mathrm{SH}$ but this trend was not evident when passage of $\mathrm{N}$ was expressed as a percentage of $\mathrm{N}$ intake (Table 7). Because the passage of NAN to the duodenum (expressed as amount and percentage of $\mathrm{N}$ intake) was not altered by treatments (Table 7), the trend for increased passage of total $\mathrm{N}$ to the duodenum indicates that the amount of $\mathrm{NH}_{3}$
$\mathrm{N}$ that passed to the duodenum also was slightly greater for diets that contained SH than corn (average 26 vs. $20 \mathrm{~g} / \mathrm{d}$ ). On average, passage of total $\mathrm{N}$ and NAN were 11 and 7\% greater than $\mathrm{N}$ intake, respectively (Table 7). Likewise, the inclusion of a fibrous byproduct in high grain diets has resulted in passage of $\mathrm{N}$ and NAN that was greater than $\mathrm{N}$ intake even though $\mathrm{N}$ intake was similar to that in our experiment (Feng et al., 1993). Our data agree with those of Mansfield and Stern (1994), indicating that the amount of NAN that passed to the duodenum did not differ when $\mathrm{SH}$ replaced corn in diets fed to dairy cows, but Cunningham et al. (1993) reported that NAN passage to the duodenum tended to be decreased. Likewise, passage of NANMN to the duodenum was not significantly different among treatments when expressed as an absolute amount, as a percentage of NAN, or as a percentage of $\mathrm{N}$ intake (Table 7). This agrees with data from a number of other experiments in which $\mathrm{SH}$ were used to replace grain in 
diets of dairy cows (Cunningham et al., 1993; Mansfield and Stern, 1994; Pantoja et al., 1994).

Replacing corn in the diet of dairy cows with SH did not significantly affect the amount of microbial $\mathrm{N}$ that passed to the duodenum (Table 7), which averaged 304 $\mathrm{g} / \mathrm{d}$ for all treatments. This value is slightly greater than the mean of $265 \mathrm{~g} / \mathrm{d}$ calculated by Clark et al. (1992) from a summary of 152 dietary treatments, many of which had a lower DMI than was observed in our trial. Passage of microbial $\mathrm{N}$ to the duodenum as a percentage of NAN passage to the duodenum also was not significantly affected by treatments. Our data agree with those from other studies in that the complete or partial replacement of corn with $\mathrm{SH}$ did not affect (Mansfield and Stern, 1994) or increased (Grigsby et al., 1993) microbial protein synthesis.

Efficiency of microbial protein synthesis expressed as grams of microbial protein synthesized per kilogram of OM apparently digested in the rumen, or as grams of microbial protein synthesized per kilogram of OM truly digested in the rumen, was not different among treatments. Other researchers also reported that replacing corn with SH in diets for dairy cows (Cunningham et al., 1993; Mansfield and Stern, 1994; Pantoja et al., 1994) did not affect the efficiency of microbial protein synthesis.

Recently, the NRC (2001) concluded that the use of $\mathrm{OM}$ apparently digested in the total tract provides a more accurate estimation of the efficiency of microbial protein synthesis than the use of ruminally fermentable OM. In our experiment, the calculation of efficiency of microbial protein synthesis using grams of microbial $\mathrm{N}$ that passed to the duodenum per kilogram of $\mathrm{OM}$ apparently digested in the total tract resulted in less variable estimations, and efficiency increased linearly as $\mathrm{SH}$ replaced corn in the diet (Table 7). Because OM digestibility in the total tract was similar among treatments, it appears that the nonsignificant increase in microbial $\mathrm{N}$ synthesis for the $\mathrm{SH}$ diets was sufficient to cause this response. Therefore, enhanced efficiency of microbial protein synthesis might have arisen from the increased intake of AA by cows fed the diets that contained SH (Table 8). These observations are in general agreement with data indicating that microbial growth or efficiency of growth improved when ruminal microbes were able to derive a greater proportion of their $\mathrm{N}$ requirements from $\mathrm{AA}$ or peptides (Cotta and Russell, 1982; Griswold et al., 1996).

Postruminal digestibility of $\mathrm{N}$ expressed as grams per day, percentage of $\mathrm{N}$ intake, and as a percentage of $\mathrm{N}$ passage to the duodenum was unaffected by treatments (Table 7). Likewise, digestibility of $\mathrm{N}$ in the total gastrointestinal tract did not differ among treatments and averaged $67.2 \%$ (Table 7). Similar to results from this experiment, other researchers have reported no change in digestibility of $\mathrm{N}$ when $\mathrm{SH}$ replaced cereal grains in diets fed to lactating dairy cows (Sarwar et al., 1992; Cunningham et al., 1993; Pantoja et al., 1994).

\section{Amino Acid Intake and Passage to Duodenum}

The incremental substitution of $\mathrm{SH}$ for corn linearly increased the intake of most individual AA, except for Leu, Phe, Val, Ala, Glu, and Pro, causing a linear increase in the ingestion of total essential AA (EAA), total nonessential AA (NEAA), and total AA (Table 8). However, the differences for His, Ile, Leu, Phe, Val, Ala, Glu, Pro, total EAA, total NEAA, and total AA between the corn-based control diet and the average of the four diets that contained $\mathrm{SH}$ were not significant. Because the content of Lys, Arg, Asp, Gly, and Ser is usually larger in protein from $\mathrm{SH}$ than from corn (Ipharraguerre and Clark, 2002), enhanced intake of these AA, or at least some of them, might be expected when $\mathrm{SH}$ replace relatively large proportions of corn and that is what we observed (Table 8). Data from another report (Cunningham et al., 1993) suggest that the intake of other AA, particularly Met, should not increase or might even decrease, as was reported by Mansfield and Stern (1994). Therefore, our results can be explained by the differences in the AA composition of the corn and soy proteins and by the slightly greater $\mathrm{N}$ intake by cows fed the diets that contained 20, 30 , and $40 \% \mathrm{SH}$.

The amount of total EAA, total NEAA, and total AA of NANMN origin that passed to the duodenum was not affected by dietary treatments (Table 9). Although the intake of several individual EAA increased when diets that contained $\mathrm{SH}$ were fed, Lys was the only EAA of NANMN origin to increase in passage to the duodenum (Table 9). Among the individual NEAA of NANMN origin, only the passage to the duodenum of Gly increased and passage to the duodenum of Asp and Ser tended to increase for cows fed diets that contained SH (Table 9).

Passage to the duodenum of individual AA, total EAA, total NEAA, and total AA of microbial origin did not differ among diets (Table 10). The replacement of corn with $\mathrm{SH}$ resulted in a linear increase for passage to the duodenum of total Lys and Gly from NANMN plus microbial $\mathrm{N}$ and a trend for a linear increase for total Asp and Ser (Table 11). This effect was probably due to the larger intakes of these AA when diets that contained SH were fed and because of the nonsignificant but numerical increase in passage to the duodenum of these AA in microbial CP.

Our data agree with previous data (Cunningham et al., 1993; Mansfield and Stern, 1994) indicating that 
Table 8. Least squares means for intakes of AA by lactating dairy cows fed diets containing different amounts of soyhulls.

\begin{tabular}{|c|c|c|c|c|c|c|c|c|c|c|}
\hline \multirow[b]{3}{*}{ AA } & \multirow{2}{*}{\multicolumn{5}{|c|}{ Soyhulls in diet, ${ }^{1} \%$}} & \multirow[b]{3}{*}{ SEM } & \multicolumn{4}{|c|}{ Contrast } \\
\hline & & & & & & & \multirow[b]{2}{*}{$\mathrm{SH}$ vs. $\mathrm{C}^{2}$} & \multirow[b]{2}{*}{ Linear } & \multirow[b]{2}{*}{ Quadratic } & \multirow{2}{*}{$\begin{array}{l}40 \mathrm{SH}^{2} \\
\text { vs. } \mathrm{C}^{2}\end{array}$} \\
\hline & 0 & 10 & 20 & 30 & 40 & & & & & \\
\hline & & & $(\mathrm{g} / \mathrm{d})$ & & & & & $-(P<)$ & & \\
\hline \multicolumn{11}{|l|}{ Essential } \\
\hline Arg & 134 & 143 & 150 & 159 & 172 & 9.8 & 0.02 & 0.001 & $\mathrm{NS}^{3}$ & 0.002 \\
\hline His & 71 & 73 & 77 & 81 & 83 & 4.9 & NS & 0.02 & NS & 0.04 \\
\hline Ile & 140 & 143 & 151 & 160 & 164 & 9.4 & NS & 0.01 & NS & 0.03 \\
\hline Leu & 297 & 291 & 298 & 303 & 300 & 18.5 & NS & NS & NS & NS \\
\hline Lys & 151 & 163 & 182 & 200 & 224 & 12.5 & 0.002 & 0.0001 & NS & 0.0001 \\
\hline Met & 42 & 47 & 45 & 50 & 49 & 2.4 & 0.02 & 0.02 & NS & NS \\
\hline Phe & 157 & 158 & 162 & 167 & 170 & 10.3 & NS & NS & NS & NS \\
\hline Thr & 121 & 127 & 136 & 148 & 149 & 9.4 & 0.03 & 0.005 & NS & 0.01 \\
\hline Val & 178 & 175 & 184 & 190 & 193 & 10.9 & NS & NS & NS & NS \\
\hline Total & 1278 & 1297 & 1362 & 1430 & 1475 & 86.7 & NS & 0.03 & NS & 0.05 \\
\hline \multicolumn{11}{|c|}{ Nonessential } \\
\hline Ala & 268 & 261 & 265 & 274 & 264 & 17.9 & NS & NS & NS & NS \\
\hline Asp & 323 & 327 & 355 & 376 & 394 & 22.0 & 0.05 & 0.003 & NS & 0.008 \\
\hline Glu & 463 & 460 & 479 & 485 & 494 & 30.0 & NS & NS & NS & NS \\
\hline Gly & 155 & 168 & 189 & 212 & 223 & 11.8 & 0.0006 & 0.0001 & NS & 0.0001 \\
\hline Pro & 229 & 222 & 236 & 230 & 235 & 13.6 & NS & NS & NS & NS \\
\hline Ser & 163 & 166 & 177 & 187 & 195 & 11.5 & 0.09 & 0.008 & NS & 0.02 \\
\hline Tyr & 84 & 92 & 98 & 111 & 124 & 7.1 & 0.003 & 0.0001 & NS & 0.0001 \\
\hline Total & 1684 & 1696 & 1798 & 1875 & 1929 & 109.4 & NS & 0.03 & NS & 0.06 \\
\hline Total AA & 2962 & 2993 & 3160 & 3304 & 3403 & 195.9 & NS & 0.03 & NS & 0.05 \\
\hline
\end{tabular}

${ }^{1}$ Soyhull were substituted for corn in the experimental diets.

${ }^{2} \mathrm{SH}$ vs. $\mathrm{C}=$ Soyhulls diets vs. control diet, $40 \mathrm{SH}$ vs. $\mathrm{C}=40 \%$ soyhull diet vs. control diet.

${ }^{3} \mathrm{NS}=$ Nonsignificant $(P>0.10)$.

Table 9. Least squares means for passage of nonammonia nonmicrobial AA to the duodenum of lactating dairy cows fed diets containing different amounts of soyhulls.

\begin{tabular}{|c|c|c|c|c|c|c|c|c|c|c|}
\hline \multirow[b]{3}{*}{$\mathrm{AA}$} & \multirow{2}{*}{\multicolumn{5}{|c|}{ Soyhulls in diet, ${ }^{1} \%$}} & \multirow[b]{3}{*}{ SEM } & \multicolumn{4}{|c|}{ Contrast } \\
\hline & & & & & & & \multirow[b]{2}{*}{$\mathrm{SH}$ vs. $\mathrm{C}^{2}$} & \multirow[b]{2}{*}{ Linear } & \multirow[b]{2}{*}{ Quadratic } & \multirow{2}{*}{$\begin{array}{l}40 \mathrm{SH} \\
\text { vs. } \mathrm{C}^{2}\end{array}$} \\
\hline & 0 & 10 & 20 & 30 & 40 & & & & & \\
\hline & & & $(\mathrm{g} / \mathrm{d})$ & & & & & $-(P<)$ & & \\
\hline \multicolumn{11}{|l|}{ Essential } \\
\hline Arg & 72 & 68 & 64 & 65 & 56 & 10.8 & $\mathrm{NS}^{3}$ & NS & NS & NS \\
\hline His & 36 & 38 & 40 & 42 & 40 & 3.7 & NS & NS & NS & NS \\
\hline Ile & 60 & 66 & 67 & 70 & 68 & 7.0 & NS & NS & NS & NS \\
\hline Leu & 153 & 150 & 151 & 154 & 136 & 16.3 & NS & NS & NS & NS \\
\hline Lys & 84 & 102 & 101 & 118 & 112 & 10.1 & 0.01 & 0.01 & NS & 0.02 \\
\hline Met & 18 & 12 & 15 & 23 & 12 & 4.8 & NS & NS & NS & NS \\
\hline Phe & 77 & 81 & 79 & 84 & 77 & 9.4 & NS & NS & NS & NS \\
\hline Thr & 61 & 66 & 67 & 69 & 65 & 6.6 & NS & NS & NS & NS \\
\hline Val & 69 & 80 & 76 & 80 & 78 & 8.1 & NS & NS & NS & NS \\
\hline Total & 621 & 664 & 650 & 684 & 632 & 70.0 & NS & NS & NS & NS \\
\hline \multicolumn{11}{|c|}{ Nonessential } \\
\hline Ala & 89 & 96 & 95 & 94 & 88 & 9.9 & NS & NS & NS & NS \\
\hline Asp & 125 & 145 & 149 & 154 & 152 & 15.6 & 0.08 & NS & NS & NS \\
\hline Glu & 238 & 236 & 240 & 242 & 217 & 24.5 & NS & NS & NS & NS \\
\hline Gly & 78 & 90 & 94 & 108 & 111 & 9.9 & 0.02 & 0.004 & NS & 0.007 \\
\hline Pro & 108 & 108 & 115 & 111 & 100 & 13.6 & NS & NS & NS & NS \\
\hline Ser & 76 & 86 & 93 & 95 & 91 & 9.1 & 0.08 & 0.10 & NS & NS \\
\hline Tyr & 31 & 45 & 36 & 39 & 38 & 8.5 & NS & NS & NS & NS \\
\hline Total & 745 & 806 & 821 & 844 & 797 & 84.7 & NS & NS & NS & NS \\
\hline Total AA & 1366 & 1470 & 1471 & 1527 & 1430 & 154.0 & NS & NS & NS & NS \\
\hline
\end{tabular}

${ }^{1}$ Soyhulls were substituted for corn in the experimental diets.

${ }^{2} \mathrm{SH}$ vs. $\mathrm{C}=$ Soyhull diets vs. control diet, $40 \mathrm{SH}$ vs. $\mathrm{C}=40 \%$ soyhull diet vs. control diet.

${ }^{3} \mathrm{NS}=$ Nonsignificant $(P>0.10)$. 
Table 10. Least squares means for passage of microbial AA to the duodenum of lactating dairy cows fed diets containing different amounts of soyhulls.

\begin{tabular}{|c|c|c|c|c|c|c|c|c|c|c|}
\hline \multirow[b]{3}{*}{ AA } & \multirow{2}{*}{\multicolumn{5}{|c|}{ Soyhulls in diet, ${ }^{1} \%$}} & \multirow[b]{3}{*}{ SEM } & \multicolumn{4}{|c|}{ Contrast } \\
\hline & & & & & & & \multirow[b]{2}{*}{ SH vs. $\mathrm{C}^{2}$} & \multirow[b]{2}{*}{ Linear } & \multirow[b]{2}{*}{ Quadratic } & \multirow{2}{*}{$\begin{array}{l}40 \mathrm{SH} \\
\text { vs. } \mathrm{C}^{2}\end{array}$} \\
\hline & 0 & 10 & 20 & 30 & 40 & & & & & \\
\hline & & 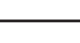 & $(\mathrm{g} / \mathrm{d})$ & & $\ldots$ & 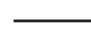 & 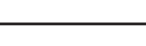 & $-(P<)$ & & \\
\hline \multicolumn{11}{|l|}{ Essential } \\
\hline Arg & 73 & 65 & 71 & 90 & 74 & 10.6 & $\mathrm{NS}^{3}$ & NS & NS & NS \\
\hline His & 29 & 26 & 28 & 34 & 29 & 4.1 & NS & NS & NS & NS \\
\hline Ile & 83 & 76 & 81 & 100 & 87 & 11.3 & NS & NS & NS & NS \\
\hline Leu & 125 & 113 & 121 & 150 & 128 & 16.7 & NS & NS & NS & NS \\
\hline Lys & 108 & 101 & 110 & 133 & 117 & 17.1 & NS & NS & NS & NS \\
\hline Met & 22 & 28 & 25 & 22 & 27 & 4.4 & NS & NS & NS & NS \\
\hline Phe & 82 & 74 & 80 & 98 & 86 & 11.1 & NS & NS & NS & NS \\
\hline Thr & 79 & 75 & 79 & 97 & 84 & 11.5 & NS & NS & NS & NS \\
\hline Val & 90 & 82 & 88 & 108 & 92 & 12.1 & NS & NS & NS & NS \\
\hline Total & 715 & 655 & 706 & 870 & 746 & 101.1 & NS & NS & NS & NS \\
\hline \multicolumn{11}{|c|}{ Nonessential } \\
\hline Ala & 117 & 106 & 113 & 140 & 119 & 16.1 & NS & NS & NS & NS \\
\hline Asp & 189 & 175 & 189 & 233 & 200 & 27.0 & NS & NS & NS & NS \\
\hline Glu & 200 & 182 & 196 & 240 & 206 & 27.8 & NS & NS & NS & NS \\
\hline Gly & 87 & 79 & 87 & 106 & 92 & 12.0 & NS & NS & NS & NS \\
\hline Pro & 68 & 60 & 66 & 80 & 66 & 9.1 & NS & NS & NS & NS \\
\hline Ser & 86 & 79 & 85 & 107 & 90 & 12.2 & NS & NS & NS & NS \\
\hline Tyr & 89 & 81 & 91 & 108 & 97 & 13.0 & NS & NS & NS & NS \\
\hline Total & 835 & 762 & 826 & 1016 & 870 & 116.7 & NS & NS & NS & NS \\
\hline Total AA & 1550 & 1417 & 1532 & 1886 & 1616 & 217.6 & NS & NS & NS & NS \\
\hline
\end{tabular}

${ }^{1}$ Soyhulls were substituted for corn in the experimental diets.

${ }^{2} \mathrm{SH}$ vs. $\mathrm{C}=$ Soyhull diets vs. control diet, $40 \mathrm{SH}$ vs. $\mathrm{C}=40 \%$ soyhull diet vs. control diet.

${ }^{3} \mathrm{NS}=$ Nonsignificant $(P>0.10)$.

Table 11. Least squares means for passage of AA to the duodenum of lactating dairy cows fed diets containing different amounts of soyhulls.

\begin{tabular}{|c|c|c|c|c|c|c|c|c|c|c|}
\hline \multirow[b]{3}{*}{$\mathrm{AA}$} & \multirow{2}{*}{\multicolumn{5}{|c|}{ Soyhulls in diet, ${ }^{1} \%$}} & \multirow[b]{3}{*}{ SEM } & \multicolumn{4}{|c|}{ Contrast } \\
\hline & & & & & & & \multirow[b]{2}{*}{$\mathrm{SH}$ vs. $\mathrm{C}^{2}$} & \multirow[b]{2}{*}{ Linear } & \multirow[b]{2}{*}{ Quadratic } & \multirow{2}{*}{$\begin{array}{l}40 \mathrm{SH} \\
\text { vs. } \mathrm{C}^{2}\end{array}$} \\
\hline & 0 & 10 & 20 & 30 & 40 & & & & & \\
\hline & & & $(\mathrm{g} / \mathrm{d})$ & & & & & $-(P<)$ & & \\
\hline \multicolumn{11}{|l|}{ Essential } \\
\hline Arg & 144 & 133 & 135 & 154 & 130 & 16.3 & $\mathrm{NS}^{3}$ & NS & NS & NS \\
\hline His & 64 & 64 & 67 & 77 & 69 & 6.0 & NS & NS & NS & NS \\
\hline Ile & 142 & 142 & 148 & 170 & 155 & 13.2 & NS & NS & NS & NS \\
\hline Leu & 278 & 263 & 272 & 304 & 264 & 21.9 & NS & NS & NS & NS \\
\hline Lys & 192 & 203 & 211 & 251 & 228 & 21.2 & NS & 0.04 & NS & NS \\
\hline Met & 41 & 40 & 40 & 45 & 39 & 3.1 & NS & NS & NS & NS \\
\hline Phe & 159 & 156 & 159 & 182 & 163 & 14.3 & NS & NS & NS & NS \\
\hline Thr & 140 & 141 & 146 & 166 & 150 & 13.1 & NS & NS & NS & NS \\
\hline Val & 159 & 162 & 164 & 187 & 170 & 14.6 & NS & NS & NS & NS \\
\hline Total & 1336 & 1319 & 1356 & 1553 & 1379 & 121.8 & NS & NS & NS & NS \\
\hline \multicolumn{11}{|c|}{ Nonessential } \\
\hline Ala & 206 & 202 & 208 & 234 & 207 & 17.3 & NS & NS & NS & NS \\
\hline Asp & 314 & 320 & 337 & 388 & 352 & 31.2 & NS & 0.08 & NS & NS \\
\hline Glu & 437 & 418 & 436 & 482 & 423 & 35.2 & NS & NS & NS & NS \\
\hline Gly & 165 & 169 & 180 & 214 & 203 & 16.8 & 0.08 & 0.001 & NS & 0.05 \\
\hline Pro & 176 & 168 & 181 & 191 & 166 & 16.5 & NS & NS & NS & 0.06 \\
\hline Ser & 162 & 164 & 178 & 202 & 181 & 16.2 & NS & 0.08 & NS & NS \\
\hline Tyr & 120 & 126 & 126 & 147 & 135 & 14.2 & NS & NS & NS & NS \\
\hline Total & 1580 & 1569 & 1647 & 1860 & 1667 & 142.7 & NS & NS & NS & NS \\
\hline Total AA & 2915 & 2887 & 3004 & 3413 & 3046 & 264.2 & NS & NS & NS & NS \\
\hline
\end{tabular}

${ }^{1}$ Soyhulls were substituted for corn in the experimental diets.

${ }^{2} \mathrm{SH}$ vs. C $=$ Soyhull diets vs. control diet, $40 \mathrm{SH}$ vs. $\mathrm{C}=40 \%$ soyhull diet vs. control diet.

${ }^{3} \mathrm{NS}=$ Nonsignificant $(P>0.10)$. 
Table 12. Least squares means for production and composition of milk from lactating dairy cows fed diets containing different amounts of soyhulls.

\begin{tabular}{|c|c|c|c|c|c|c|c|c|c|c|}
\hline \multirow[b]{3}{*}{ Item } & \multirow{2}{*}{\multicolumn{5}{|c|}{ Soyhulls in diet, ${ }^{1} \%$}} & \multirow[b]{3}{*}{ SEM } & \multicolumn{4}{|c|}{ Contrast } \\
\hline & & & & & & & \multirow[b]{2}{*}{$\mathrm{SH}$ vs. $\mathrm{C}^{2}$} & \multirow[b]{2}{*}{ Linear } & \multirow[b]{2}{*}{ Quadratic } & \multirow{2}{*}{$\begin{array}{l}40 \mathrm{SH} \\
\text { vs. } \mathrm{C}^{2}\end{array}$} \\
\hline & \multirow[t]{2}{*}{0} & \multirow[t]{2}{*}{10} & \multirow[t]{2}{*}{20} & \multirow[t]{2}{*}{30} & \multirow[t]{2}{*}{40} & & & & & \\
\hline & & & & & & & & & <) - & \\
\hline Milk, kg/d & 30.0 & 29.1 & 29.3 & 30.2 & 28.7 & 2.3 & $\mathrm{NS}^{3}$ & NS & NS & NS \\
\hline $3.5 \% \mathrm{FCM},{ }^{4} \mathrm{~kg} / \mathrm{d}$ & 28.3 & 27.8 & 27.3 & 28.4 & 27.7 & 1.9 & NS & NS & NS & NS \\
\hline \multicolumn{11}{|l|}{ Fat } \\
\hline$\%$ & 3.21 & 3.25 & 3.10 & 3.18 & 3.36 & 0.26 & $\mathrm{NS}$ & $\mathrm{NS}$ & NS & NS \\
\hline $\mathrm{kg} / \mathrm{d}$ & 0.95 & 0.94 & 0.91 & 0.95 & 0.94 & 0.07 & NS & NS & NS & NS \\
\hline \multicolumn{11}{|l|}{ Crude protein } \\
\hline$\%$ & 3.16 & 3.05 & 2.88 & 2.91 & 3.02 & 0.19 & NS & NS & NS & NS \\
\hline $\mathrm{kg} / \mathrm{d}$ & 0.93 & 0.88 & 0.84 & 0.87 & 0.86 & 0.06 & NS & NS & NS & NS \\
\hline \multicolumn{11}{|l|}{ True protein } \\
\hline$\%$ & 2.78 & 2.71 & 2.76 & 2.75 & 2.68 & 0.09 & NS & NS & NS & NS \\
\hline $\mathrm{kg} / \mathrm{d}$ & 0.83 & 0.79 & 0.81 & 0.83 & 0.77 & 0.06 & NS & NS & NS & NS \\
\hline \multicolumn{11}{|l|}{ Total solids } \\
\hline$\%$ & 11.60 & 11.65 & 11.49 & 11.66 & 11.70 & 0.25 & NS & NS & NS & NS \\
\hline $\mathrm{kg} / \mathrm{d}$ & 3.46 & 3.38 & 3.36 & 3.51 & 3.35 & 0.25 & NS & NS & NS & NS \\
\hline MUN, ${ }^{5} \mathrm{mg} / \mathrm{dl}$ & 12.6 & 14.0 & 13.9 & 15.2 & 16.1 & 0.96 & 0.04 & 0.008 & NS & 0.01 \\
\hline
\end{tabular}

${ }^{1}$ Soyhulls were substituted for corn in the experimental diets.

${ }^{2} \mathrm{SH}$ vs. $\mathrm{C}=$ Soyhull diets vs. control diet, $40 \mathrm{SH}$ vs. $\mathrm{C}=40 \%$ soyhull diet vs. control diet.

${ }^{3} \mathrm{NS}=$ Nonsignificant $(P>0.10)$.

${ }^{4} 3.5 \% \mathrm{FCM}=0.4324$ (kilograms of milk) +16.216 (kilograms of fat).

${ }^{5}$ Milk urea nitrogen.

the replacement of 12 to 30 percentage units of corn with SH successfully sustained microbial growth and passage of total AA to the duodenum of dairy cows. However, it has been suggested that feeding large amounts of soyhulls to lactating dairy cows (> 30\% of dietary DM; Mansfield and Stern, 1994) might limit animal performance because of an inadequate supply of Met. According to the NRC (2001), contents of Met and Lys in metabolizable protein delivered to the duodenum of dairy cows should be 2.4 and $7.2 \%$, respectively, to assure an optimal AA supply for maintenance and milk protein production. Model estimations (NRC, 2001) revealed that the concentrations of both Met and Lys in metabolizable protein were below those values for all diets in this experiment. The concentration of Met ranged from 1.90 to $1.75 \%$ of metabolizable protein for the control and $40 \% \mathrm{SH}$ diets, respectively. The concentration of Lys ranged from $6.85 \%$ to $6.55 \%$ of metabolizable protein for the $40 \% \mathrm{SH}$ and control diets, respectively. These data indicate that, under these experimental conditions, the availability of Met in duodenal contents appears to be more limiting than Lys $(-27 \%$ vs. $-9 \%)$.

\section{Production of Milk and Milk Composition}

Yields of milk and 3.5\% FCM were not affected significantly by treatments (Table 12). However, milk production was numerically decreased by $1.3 \mathrm{~kg} / \mathrm{d}$ per cow in this trial when the $40 \% \mathrm{SH}$ diet was fed and milk production was decreased by $1.2 \mathrm{~kg} / \mathrm{d}$ per cow $(P<0.07)$ in a companion study (Ipharraguerre et al., 2002) in which the same diet was fed to midlactation cows. In other trials, when SH replaced corn in the diet of dairy cows to provide $30 \%$ or more of the dietary DM, production of milk (Mansfield and Stern, 1994; Nakamura and Owen, 1989) or FCM (Nakamura and Owen, 1989) decreased.

Milk fat percentage and yield did not differ among treatments (Table 12); however, in a companion trial (Ipharraguerre et al., 2002), feeding the same diets linearly increased milk fat percentage and yield. In previous trials, milk fat percentage was either unaltered (Cunningham et al., 1993; Mansfield and Stern, 1994) or increased (Nakamura and Owen, 1989; Pantoja et al., 1994) by the replacement of cereal grain with SH.

The concentration and yield of $\mathrm{CP}$, true protein, and total solids in milk did not differ among dietary treatments (Table 12). Secretion of urea in milk (i.e., MUN) increased for cows fed SH, increasing linearly as SH replaced corn in the diet (Table 12). This is consistent with the higher concentration of $\mathrm{NH}_{3} \mathrm{~N}$ in ruminal fluid of cows fed $\mathrm{SH}$, suggesting that the amount of $\mathrm{NH}_{3} \mathrm{~N}$ absorbed from the rumen into the blood, converted to urea in the liver, and released back into the blood increased as additional SH replaced corn in the diets.

\section{CONCLUSIONS}

These data suggest that $\mathrm{SH}$ can replace corn to supply up to $30 \%$ of the DMI of midlactation cows in diets that 
contain about $50 \%$ forage without depressing energy, protein, or amino acid availability for milk production. Replacing corn with $\mathrm{SH}$ in diets that contain about $50 \%$ forage increases the intake of $\mathrm{NDF}$ and $\mathrm{ADF}$ and decreases the intake of NSC when the diet contains SH in excess of $30 \%$ of the total dietary DM. Increasing the intake of NDF and ADF increases the amounts digested in the rumen and lower gastrointestinal tract, and decreasing the intake of NSC decreases the amount digested in the rumen and lower gastrointestinal tract. These differences in the source of energy (fiber vs. NSC), in the amounts of fiber and NSC digested, and in the site of digestion in the gastrointestinal tract may cause a shortage in the source and/or amount of energy that is required for maximum milk production in high producing cows when more than $30 \%$ of the dietary DM that is supplied as corn is replaced with $\mathrm{SH}$.

\section{REFERENCES}

Association of Official Analytical Chemists. 1990. Official Methods of Analysis. Vol. I, 15th ed. AOAC, Arlington, VA.

Bremner, J. M., and D. R. Keeney. 1965. Steam distillation methods for determination of ammonium, nitrate, and nitrite. Anal. Chim. Acta 32:485-495.

Chaney, A. L., and E. P. Marbach. 1962. Modified reagents for determination of urea and ammonia. Clin. Chem. 8:130-132.

Clark, J. H., T. H. Klusmeyer, and M. R. Cameron. 1992. Microbial protein synthesis and flows of nitrogen fractions to the duodenum of dairy cows. J. Dairy Sci. 75:2304-2323.

Cotta, M. A., and J. B. Russell. 1982. Effects of peptides and amino acids on efficiency of rumen bacterial protein synthesis in continuous culture. J. Dairy Sci. 65:226-234.

Cunningham, K. D., M. J. Cecava, and T. R. Johnson. 1993. Nutrient digestion, nitrogen, and amino acid flows in lactating cows fed soybean hulls in place of forage or concentrate. J. Dairy Sci. 76:3523-3535.

Elliott, J. P., J. K. Drackley, G.C. Fahey, Jr., and R.D. Shanks. 1995. Utilization of supplemental fat by dairy cows fed diets varying in content of nonstructural carbohydrates. J. Dairy Sci. 78:1512-1525.

Erdman, R. A. 1988. Dietary buffering requirements of the lactating dairy cow. J. Dairy Sci. 71:3246-3266.

Feng, P., W. H. Hoover, T. K. Miller, and R. Blauweikel. 1993. Interactions of fiber and nonstructural carbohydrates on lactation and ruminal function. J. Dairy Sci. 76:1324-1333.

Firkins, J. L. 1997. Effects of feeding nonforage fiber sources on site of fiber digestion. J. Dairy Sci. 80:1426-1437.

Grigsby, K. N., M. S. Kerley, J. A. Paterson, and J. C. Weigel. 1993. Combinations of starch and digestible fiber in supplements for steers consuming a low-quality bromegrass hay diet. J. Anim. Sci. 71:1057-1064.

Griswold, K. E., W. H. Hoover, T. K. Miller, and W. V. Thayne. 1996. Effect of form of nitrogen on growth of ruminal microbes in continuous culture. J. Anim. Sci. 74:483-491.

Ipharraguerre, I. R., and J. H. Clark. 2002. Soyhulls as an alternative feed for lactating dairy cows: A review. J. Dairy Sci. (Accepted).

Ipharraguerre, I. R., R. R. Ipharraguerre, and J. H. Clark. 2002. Performance of lactating dairy cows fed varying amounts of soyhulls as a replacement for corn grain. J. Dairy Sci. 85:2917-2924.

Littell, R. C., G. A. Milliken, W. W. Stroup, and R. D. Wolfinger. 1996. SAS system for mixed models. SAS Institute Inc., Cary, NC.

Lykos, T., G. A. Varga, and D. Casper. 1997. Varying degradation rates of total nonstructural carbohydrates: Effects on ruminal fermentation, blood metabolites, and milk production and composition in high producing Holstein cows. J. Dairy Sci. 80:33413355.

Mansfield, H. R., and M. D. Stern. 1994. Effects of soybean hulls and lignosulfonate-treated soybean meal on ruminal fermentation in lactating dairy cows. J. Dairy Sci. 77:1070-1083.

McCarthy, R. D., Jr., T. H. Klusmeyer, J. L. Vicini, J. H. Clark, and D. R. Nelson. 1989. Effects of source of protein and carbohydrate on ruminal fermentation and passage of nutrients to the small intestine of lactating cows. J. Dairy Sci. 72:2002-2016.

Mertens, D. R. 1992. Nonstructural and structural carbohydrates. Pages 219-235 in Large Dairy Herd Management. pp. 219-235. H.H. Van Horn, and C. J. Wilcox, ed. American Dairy Science Association, Champaign, IL.

Moore, S. 1963. On the determination of cystine as cysteic acid. J. Biol. Chem. 238:235-237.

Nakamura, T., and F. G. Owen. 1989. High amounts of soyhulls for pelleted concentrate diets. J. Dairy Sci. 72:988-994.

Nocek, J. E. 1997. Bovine acidosis: Implications on laminitis. J. Dairy Sci. 80:1005-1028.

Nocek, J. E., and S. Tamminga. 1991. Site of digestion of starch in the gastrointestinal tract of dairy cows and its effect on milk yield and composition. J. Dairy Sci. 74:3598-3629.

National Research Council. 1989. Nutrient Requirements of Dairy Cattle. 6th rev. ed. Natl. Acad. Sci., Washington, DC.

National Research Council. 2001. Nutrient Requirements of Dairy Cattle. 7th rev. ed. Natl. Acad. Sci., Washington, DC.

Overton, T. R., M. R. Cameron, J. P. Elliott, J. H. Clark, and D. R. Nelson. 1995. Ruminal fermentation and passage of nutrients to the duodenum of lactating cows fed mixtures of corn and barley. J. Dairy Sci. 78:1981-1998.

Pantoja, J., J. L. Firkins, M. L. Eastridge, and B. L. Hull. 1994. Effects of fat saturation and source of fiber on site of nutrient digestion and milk production by lactating dairy cows. J. Dairy Sci. 77:2341-2356.

Sarwar, M., J. L. Firkins, and M. L. Eastridge. 1991. Effect of replacing neutral detergent fiber of forage with soyhulls and corn gluten feed for dairy heifers. J. Dairy Sci. 74:1006-1017.

Sarwar, M., J. L. Firkins, and M. L. Eastridge. 1992. Effects of varying forage or concentrate carbohydrates on nutrient digestibilities and milk production by dairy cows. J. Dairy Sci. 75:1533-1542.

SAS. 2000. The SAS System for Windows. Release 8.1 (TS1 MO). SAS Institute, Inc. Cary, NC.

Satter, L. D., and L. L. Slyter. 1974. Effect of ammonia concentration on rumen microbial protein production in vitro. Br. J. Nutr. 32:199-208.

Smith, D. 1981. Removing and analyzing carbohydrates from plant tissue. Wisconsin Agric. Exp. Stn. Rep. No. R 2107, Madison, WI.

Stokes, S. R., W. H. Hoover, T. K. Miller, and R. Blauweikel. 1991. Ruminal digestion and microbial utilization of diets varying in type of carbohydrates and protein. J. Dairy Sci. 74:871-881.

Stone, W. C. 1996. Applied topics in dairy cattle nutrition. I. Soyhulls as either forage or concentrate replacement. Ph.D. Thesis. Cornell Univ., Ithaca, NY.

Supelco, Inc. 1975. GC Separation of VFA C2-C5. Tech. Bull. 749D. Supelco, Inc., Bellefonte, PA

Titgemeyer, E. C. 2000. Soy byproducts as energy sources for beef and dairy cattle. Pages 238-256 in Soy in Animal Nutrition. J.K. Drackley, ed. Fed. Anim. Sci. Soc., Savoy, IL.

Van Soest, P. J., J. B. Robertson, and B. A. Lewis. 1991. Methods for dietary fiber, neutral detergent fiber, and nonstarch polysaccharides in relation to animal nutrition. J. Dairy Sci. 74:35833597.

Williams, C. H., D. J. David, and O. Iismaa. 1962. The determination of chromic oxide in faeces samples by atomic absorption spectrophotometry. J. Agric. Sci. 59:381-385.

Zinn, R. A., and F. N. Owens. 1986. A rapid procedure for purine measurement and its use for estimating net ruminal protein synthesis. Can. J. Anim. Sci. 66:157-166. 